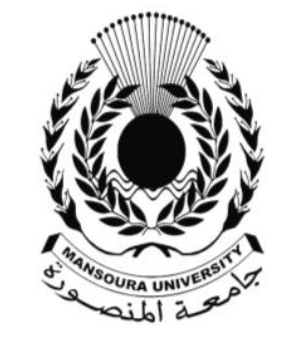

جامعة المنصـورة الماندة

$$
\text { كليـة الآداب }
$$

\title{
حركة الموصل
}

\author{
إعــــد \\ عمر سلمان نامس \\ باحث لدرجة الماجستير فى الآداب قسم التاريخ \\ كلية الآداب - جامعة المنصورة
}

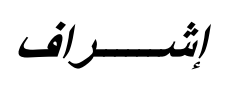

أ. د. / إبراهيه عبدا لمجيد محمد المد

أستاذ التاريخ الحديث المعاصر

كلية الآداب- جامعة المنصورة

مجـلة كلــية الآداب - جامعــة المنصـورة

العدد الثامز و الخمسوز -يناير r.17 


\section{هركـــة الموصــل}

\section{عمر سلمان نامس}

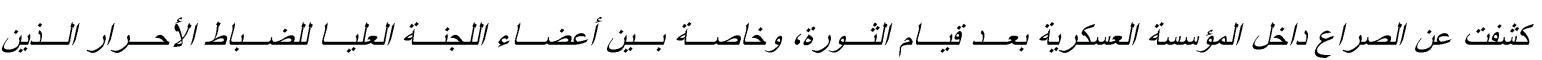

$$
\begin{aligned}
& \text { اثترك بعضهم فعليًا فيها بوم الثورة. } \\
& \text { كثفت عن عمق وقوة الثعور بالوحدة العربية والقومبة العربية والمنادين بها. }
\end{aligned}
$$

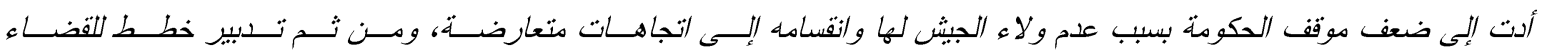

$$
\begin{aligned}
& \text { على النظام القائم. }
\end{aligned}
$$

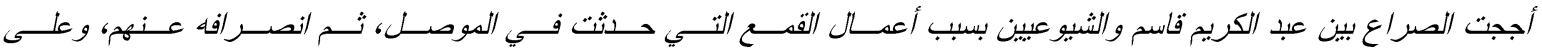

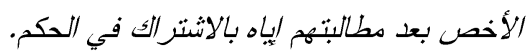

$$
\begin{aligned}
& \text { أدت إلى عزلة عبد الكريم قاسم بين الأفطار العربية وازدياد الحملات الإعلامية ضد نظام حكمه. }
\end{aligned}
$$

\section{Abstract}

unveiled a conflict within the military after the revolution, especially among the members of the Supreme Committee of the Free Officers who participated in some of them actually Revolution Day.

revealed the depth and strength of loneliness and Arab nationalism and Arab advocates of it.

led to the weakness of the government's position because of the loyalty of the army and its division into opposite directions, and then the management plans for the elimination of the existing system.

fueled conflict between Abdel-Karim Kassem and the Communists because of the repression that occurred in Mosul, then his departure from them, especially after their demand for him to participate in the ruling.

led to the isolation of Abdul Karim Qasim between the Arab countries and the increase in media campaigns against his regime.

\section{أولًا : الموقفت في الموصل}

وعقب ثــورة ع ا تمــوز عــام 1901

كان هناك في المدينــة اتجاهـــان متعارضــــان، أولهما قومي وحــدوي، فــي مقدمتــه حـزبـ

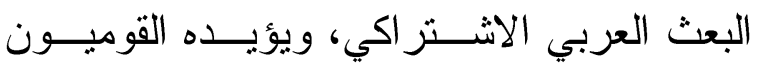

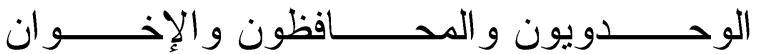
المسلمون و عدد من الملاكك وشــيوخ العشـائر

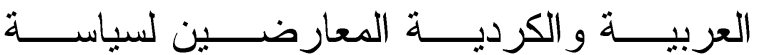

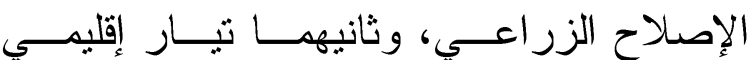

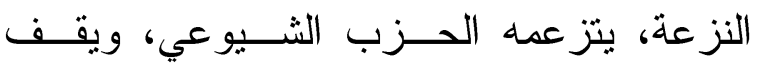

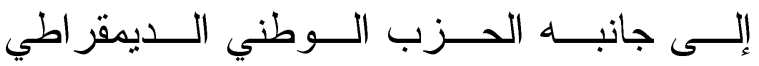

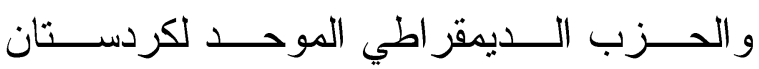

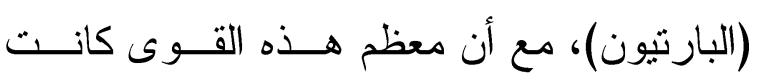
متألفة في جبهة الاتحاد الوطني قبــلـ الثـورة،

عرفت مدينـــة الموصــلـ منــذ وقــت

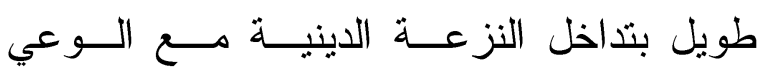
القومي، الأمر الذي أهلها لأن تكــون مركـزاً

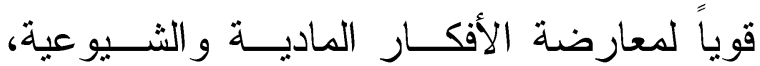

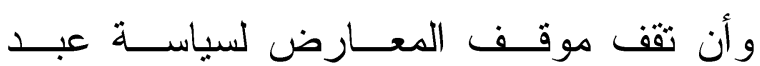

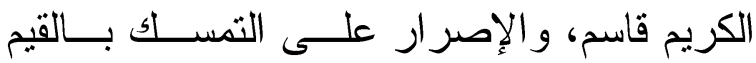

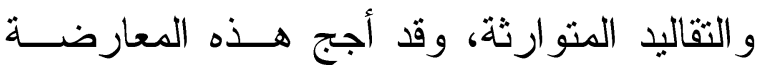

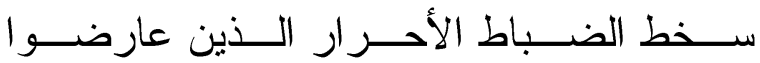

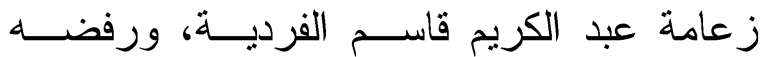

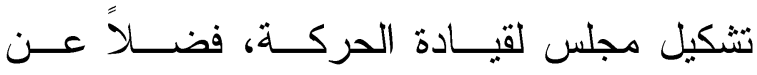

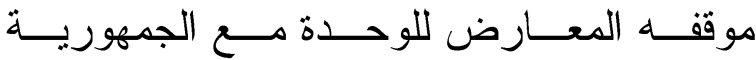
العربية المتحدة. (') 
ذلك التقدير بعد إبعاد عبد السلام عــارف لــه،

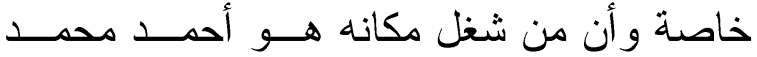
بحيى الذي كان الشواف ينظر إليه علــى أنـــه

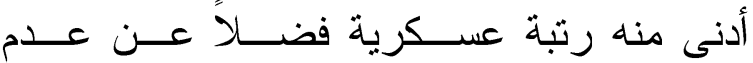

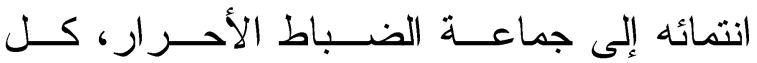
ذلك جعل الشواف يعيش فــي عزلـــة، و أظهـــر

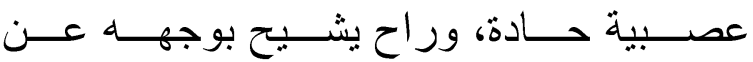
حكومة عبد الكريم قاسم.(£)

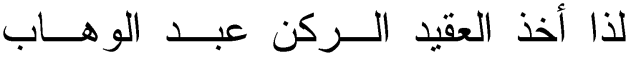
الشو اف يفكر بــالتمرد و الإطاحسـة بكــل مــن

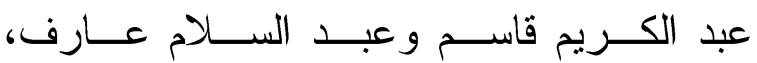
فشرع بالاتصــال بالضــباط الأحــرار الــــي

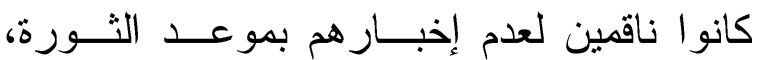
ولعدم تشكيل مجلس قيادة الثورة، فضــلاً عــن بـن

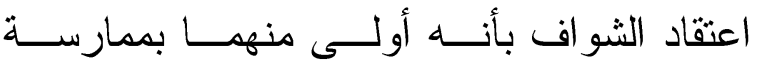

(ن) السلطة.

و استطاع الثـــو اف أن يجمــع حولــه

العقيد الركن عبد الرحمن عبــد الســتار آهــر

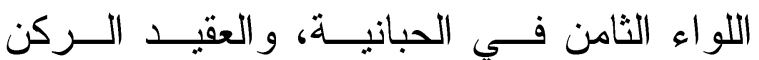

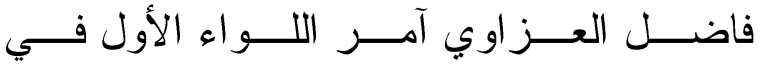

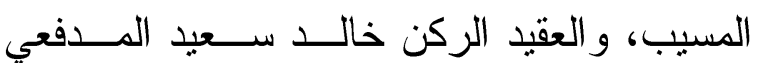
آمر الفــوج الأول للـــواء التاســـع عشـــر فــي

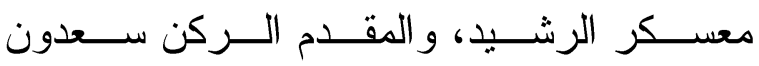
حسين آمــر الفــوج الثــاني للــواء العشــرين

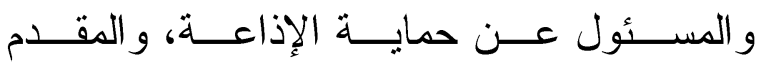

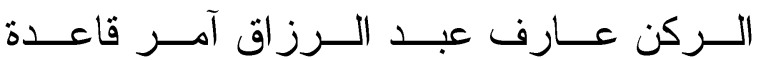
الحبانية، و الر ائد خزعل الســعدي آهــر كتيــــة دبابات، و الرائد خليـلـل العلــي آهــر مدرســـة
لكنها سرعان ما أخفقت منــــ الأيــام الأولــى للثثورة بسبب طبيعة الثـــعار ات التـي رفعهــا

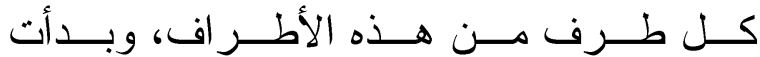
المحاو لات و المناقشـــات تــدور فـــي المقـــــي و المجالس العامة و الأســـواق، وكـــان الاتجـــاه القومي الوحدوي هـــو الأقــوى فـــي المدينــة سواء من حيــث العــدد أو التتظــيم أو الــدعم الجماهيري و العسكري. (r) وظهرت في الموصــل نكــنلات مــن الضباط المعارضين لحكم عبد الكــريم قاســم، أولهما يمثله عدد من الضباط الأحــرار مدــن نقلو ا إلى اللو اء الخــــس فــي الموصــل مــن

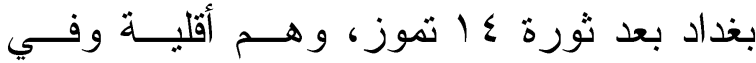

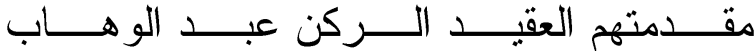
الشو اف (*) (r)

فعندما نجحت ثـورة ع ا تمــوز عــام

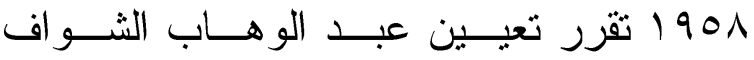

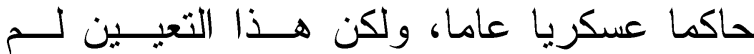
ينل موافقة العقبد الركن عبــد الســـلام عـــارف الذي لم يكن يرتاح إلى الشو اف فــأر اد إبعــاده

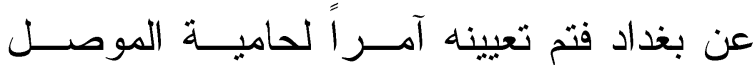

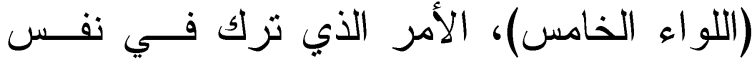
الشواف أثراً عميقاً، إذ كان فــي بدايـــة الأمـــر يعتقد أن مهمته في الموصــل مهمــة مؤقتــة، و أنها ستتتهي حالما يتم تشــكيل مجلـس قيــادة

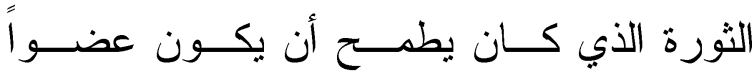

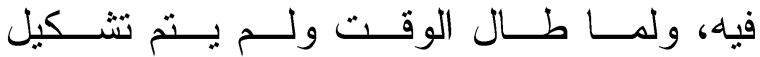
المجلس أخذ الشواف يشعر بــأن تعيينـــه هــــا

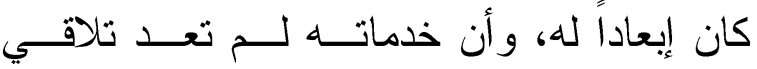




\section{ثانياً : الموقف في بغلداد}

وفي بغداد كـان عــد مــن الضــباط

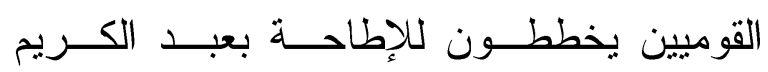

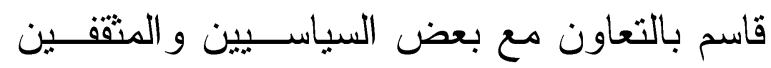

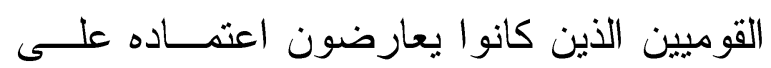

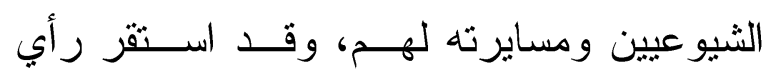

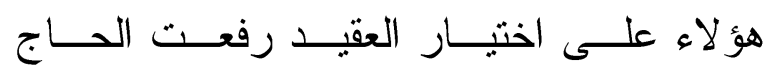

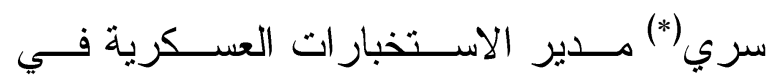

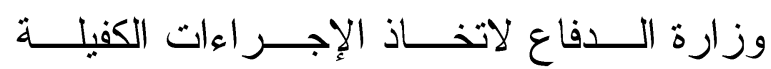

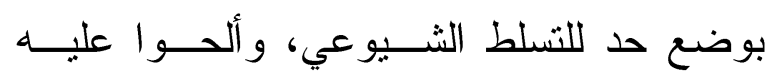

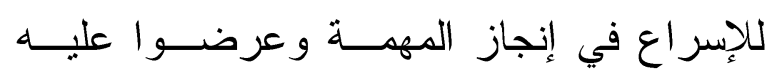

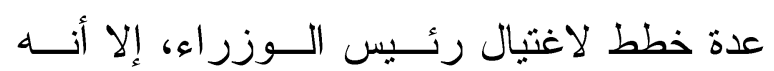
رفض ذلك بسبب قوة النفــوذ الثــيوعي فــي

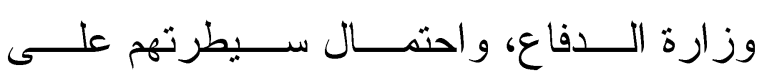

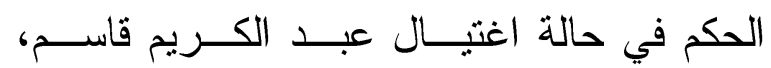

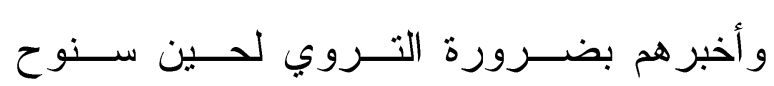
(الفرصة. وقام بتثــكبل لجنــة لار اســـة الأمــر،

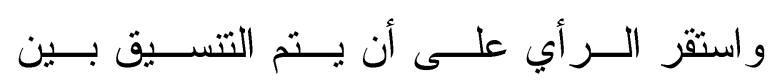

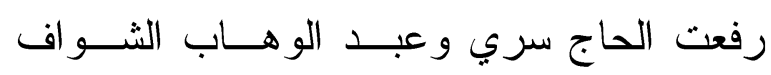

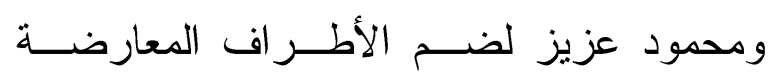

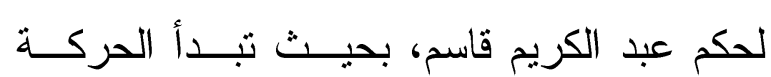

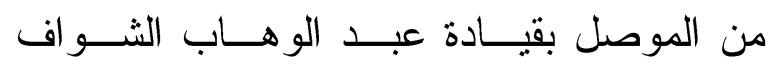

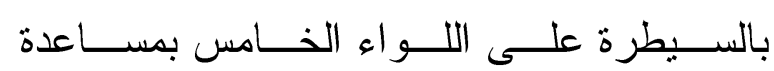
محمود عزيـز و الضـــباط الثـائرون و إعــلان

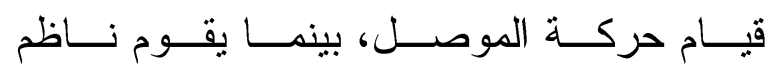

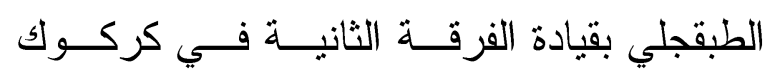

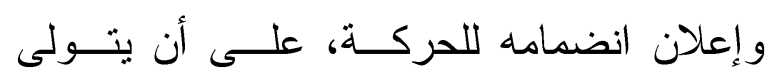

العجلات المدرعة، ومحمد علــي سـعيد مـن الاستخبار ات العسكرية.(†) أما التكتل الثاني مــن الضــــاط فكـــان

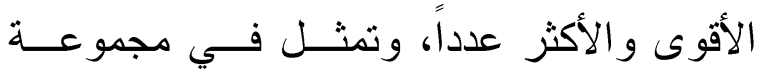

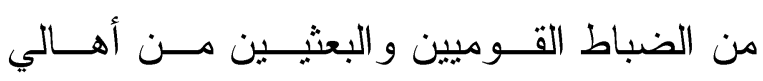
الموصل، وعرفــوا باســم تتظــيم (الضــباط

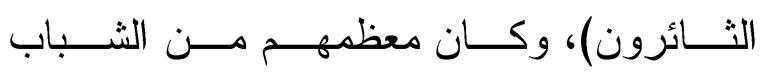

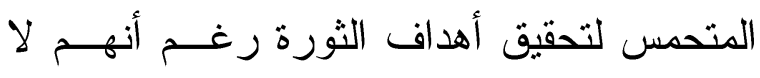

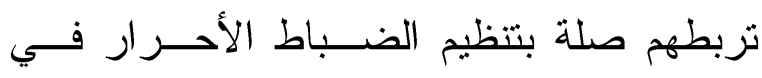

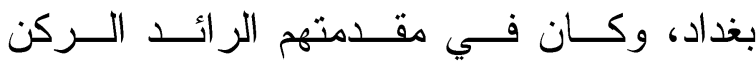

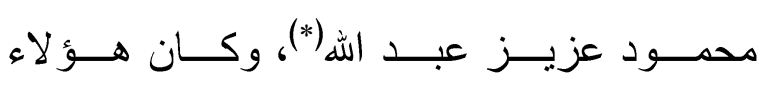

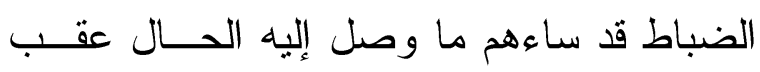

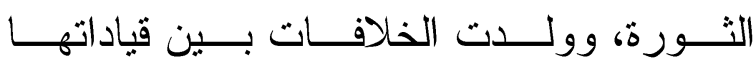

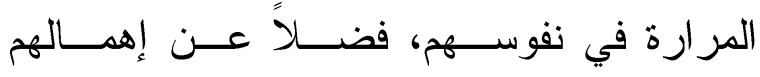

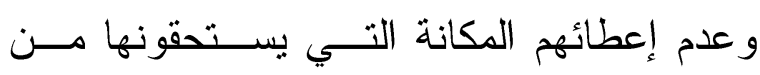

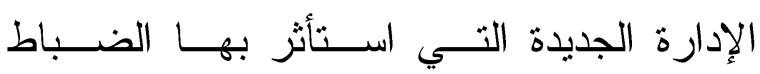

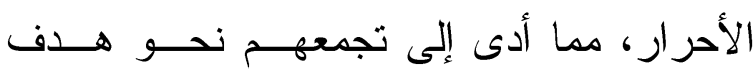

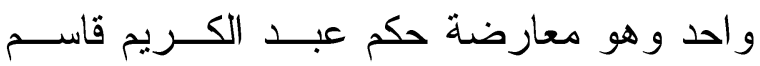

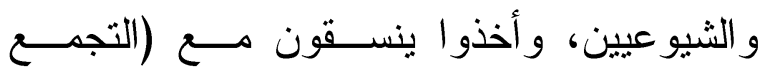

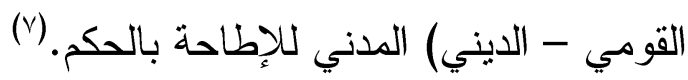

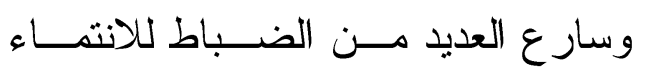

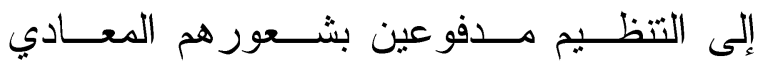

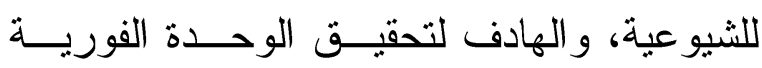

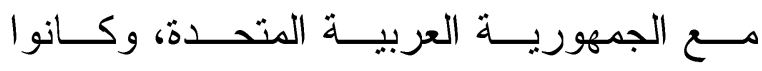

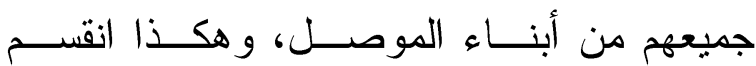
الضباط في الموصــل إلــى قســـين، جماعـــة

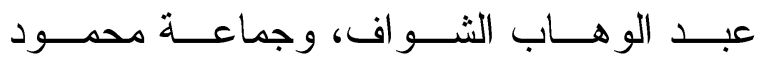
(^) عزيز 


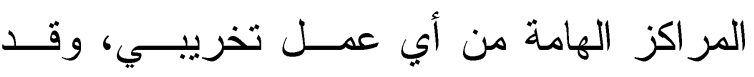

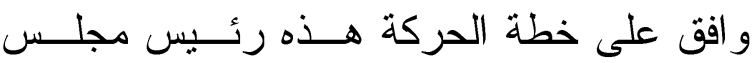

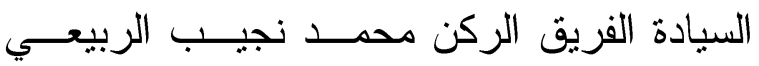

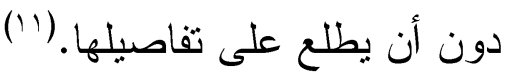
ثالثاً : أهلداف حركة الموصل

أما أهداف الحركــة فيـــكرها الــزعيم الركن ناظم الطبقجلـي فــي مذكر اتــه، ومــنـن

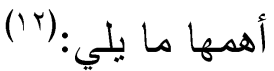
1- العراق جمهورية مســقلة ذات ســيادة، وهـي جـزءء لا يتجــز أ مــن الــوطن

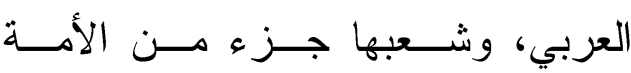

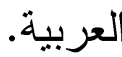
ب- الوحدة العربيــة هـــف قــومي يعهـلـ

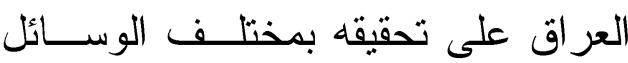

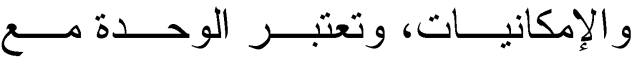

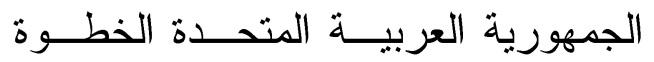
الأساسية الكبرى للوحدة العربية.

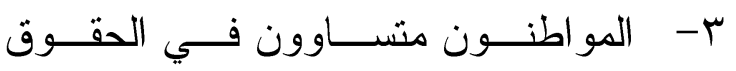
و الواجبــات، وتعتبـــر الدولـــة العــرب

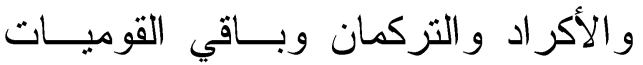

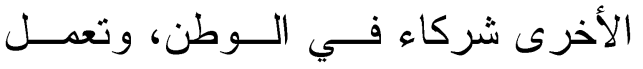

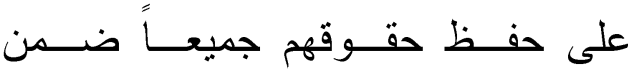

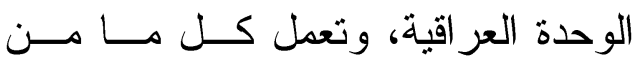

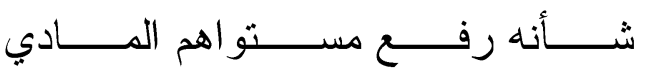

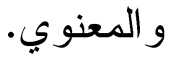
ع- تكون أهــداف البرنـــامج الاقتصـــادي

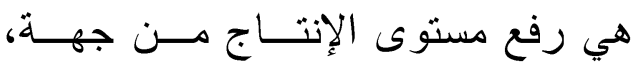

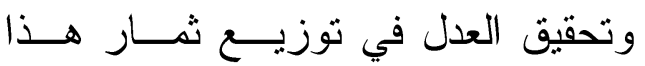

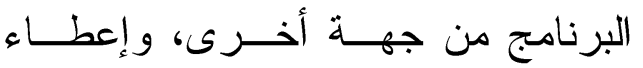

رفعت الحسـاج ســري الســيطرة علــى وزارة الدفاع و اعتقال قاسم. (1) وجاءت تفاصـيل الخطـــة بــأن بعلـنـن

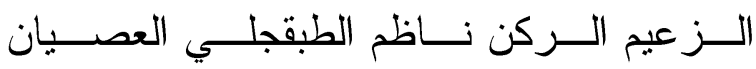

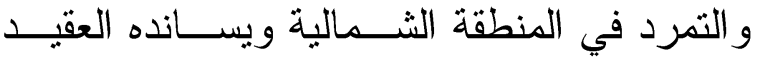

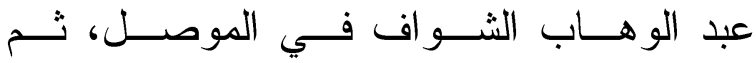
تتحرك العناصر العســكرية المؤيــــة للحركـــة في بغداد فتســتولي علــى معســكر الوشــاش بقيادة العقيد نعمان ماهر الكنعــاني، ومعسـكر

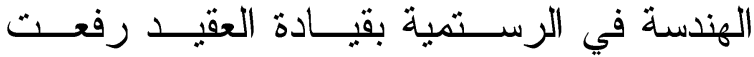
الحاج سري، وحاميــة وزارة الـــفاع بقيــادة

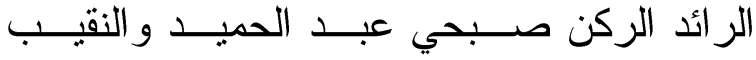
عدنان أيـوب صــبري، ثـم تقــوم عناصــر الحركة باعتقال عبدالكريم قاســم وأنصــاره، ومطالبته بتقديم استقالته ثــ مغـــادرة العــراق، فإذا رفض ذللك يقضى عليه فــي الحسـال، إذـــا في مكتبه بوزارة الدفاع أو في الطريــق أثتـــاء

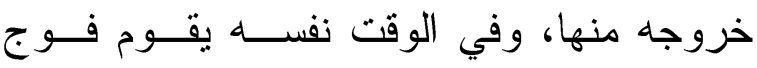

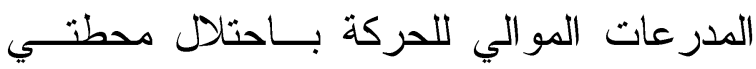

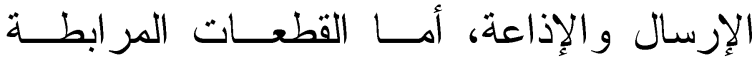

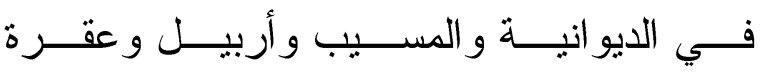

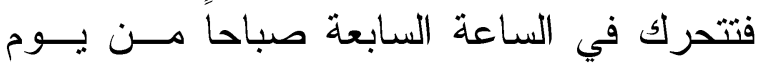

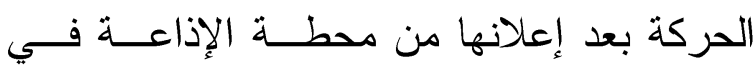

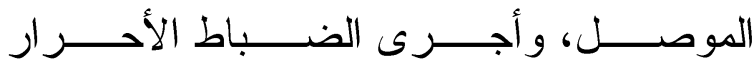

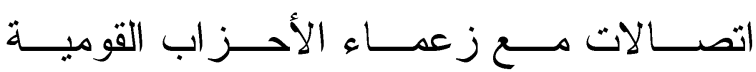

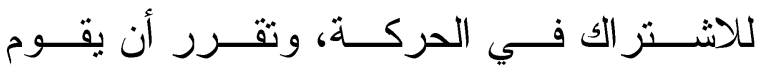

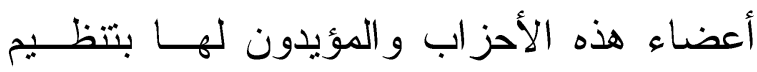

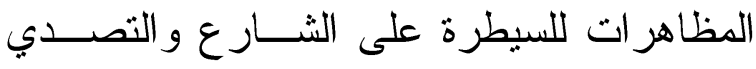

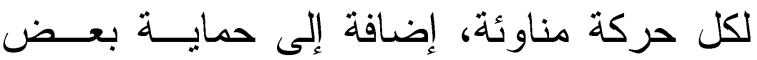


وقد حـــاول القوميــون مــــاراً إقتـــاع

عبد الكريم قاسم بحقن الــدماء ومنــع التجمـــع

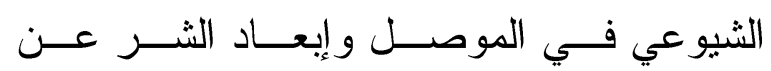

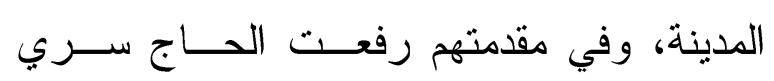

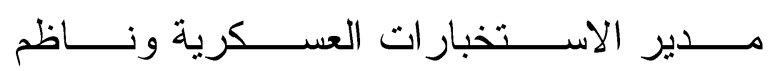

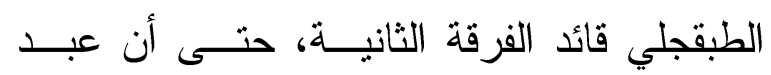

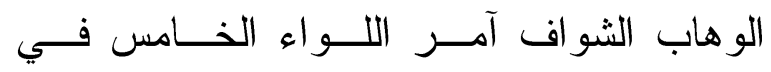

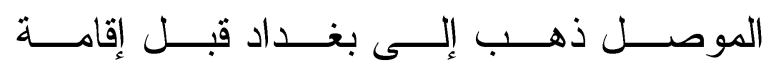

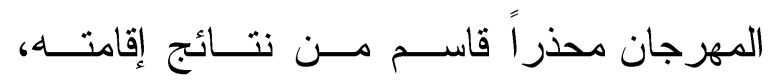

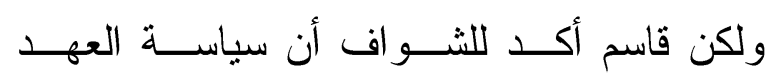
الجديد هي سياسة حياديــة تتعـــى الحزبيــات،

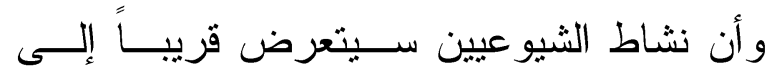
إجر اءات تحد منه.(1)

وفي صباح يــوم الجمعــة الموافـق 1

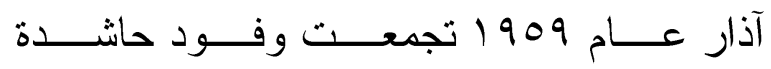
حضرت من مختلف أنحاء العــراق، وســارت

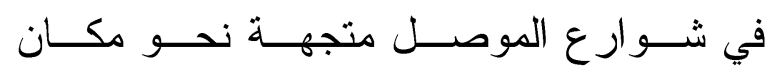

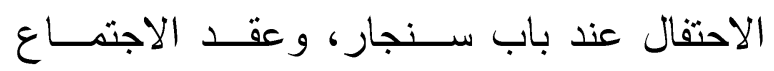

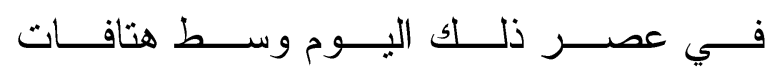

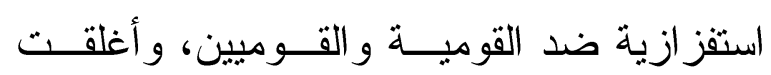

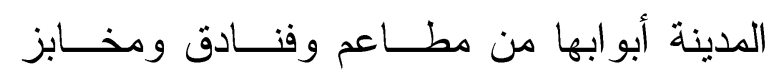

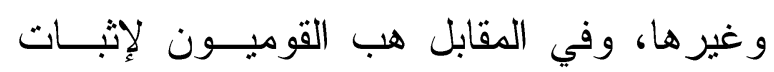

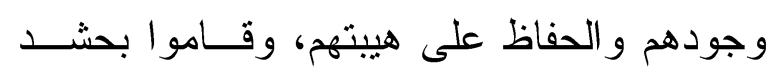

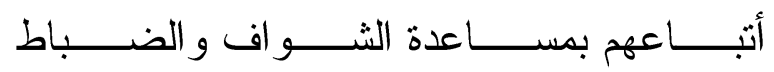

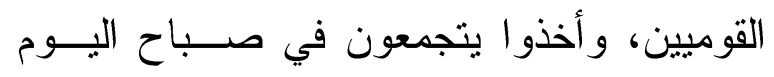

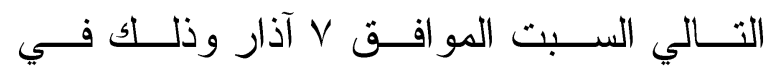

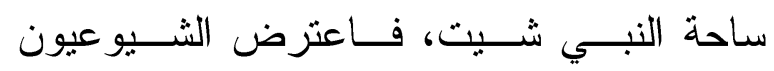

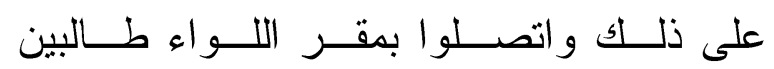

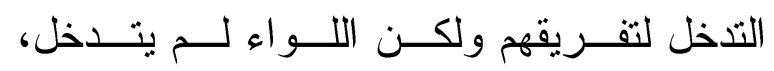

الأهمية القصوى للإصـــلاح الزراعـي

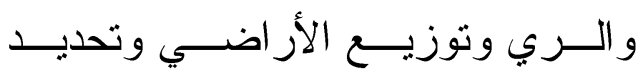

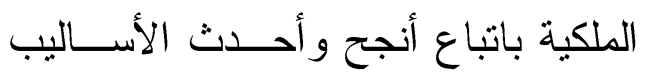
العلمية و النظرية.

\section{رابعاً : مهرجان أنصار السلام ولنطرئ}

وسط ذلـــك الجـــو المشــــون بــالقلق

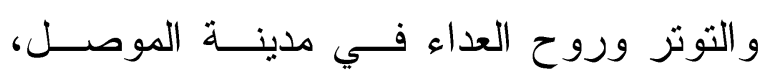

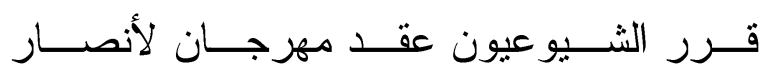
السلام في المدينة تحدياً للقوميين فيهــا، وكــان

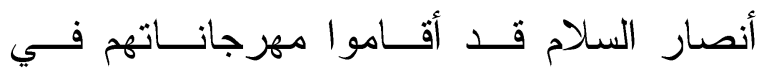

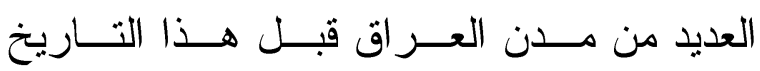

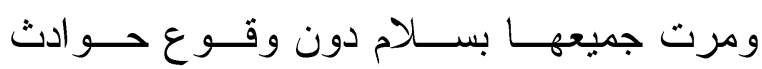

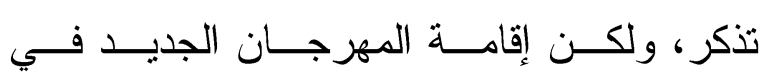

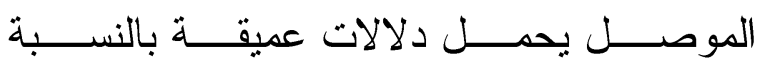

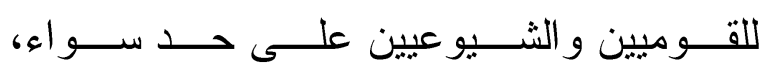

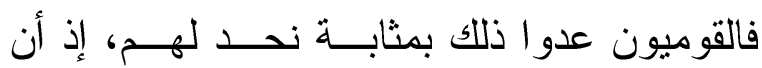

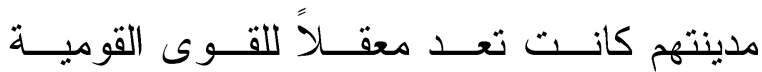
و المتمســكين بتقاليــدهم الإنـــلامية و الـــــاعين

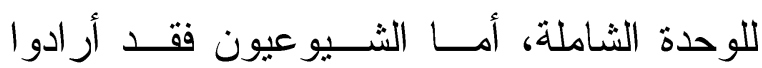

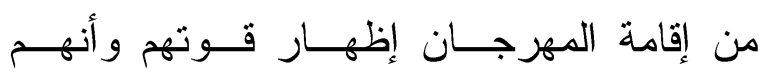

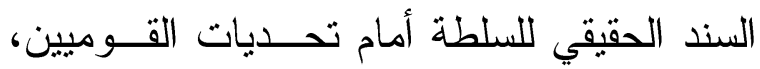
وقد أصر عبــــ الكــريم قاســـم علــى إقامـــة

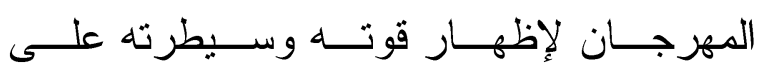

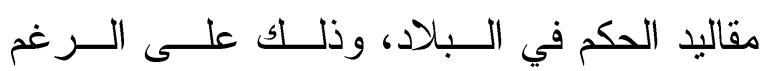

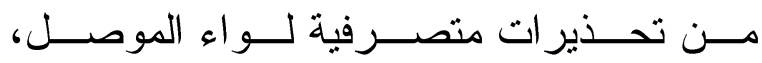

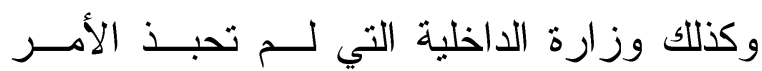

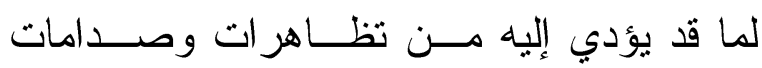
لا تعرف نتائجها.(') 
ذللك ما كان ليحول بين مضي الثـــواف قـدما

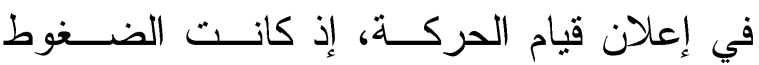
عليه كبيرة من ضباط الموصل، وكــان عليـهـ أن ينصـــاع إلـــى حماســـة محمـــود عزيــز

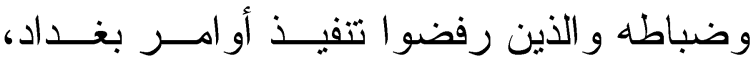

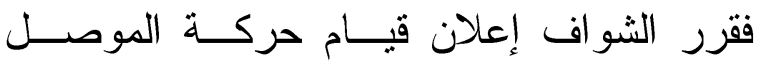

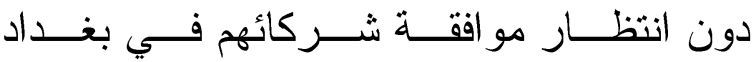

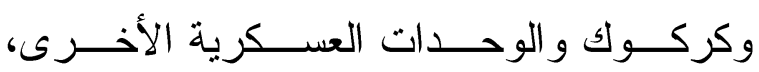

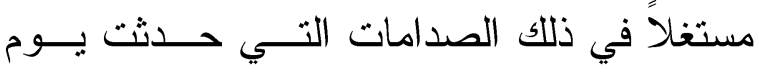

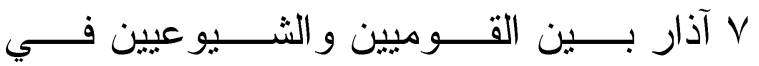
الموصل. (i)

\section{خامساً: إعلان قيام حركة الموصل}

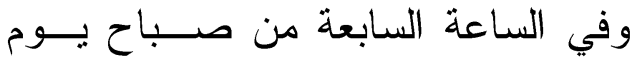

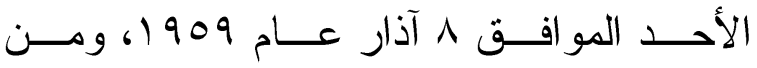

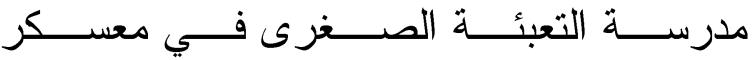

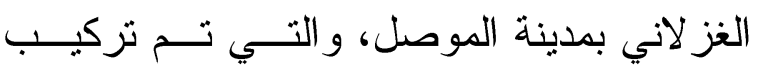

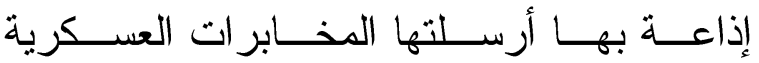

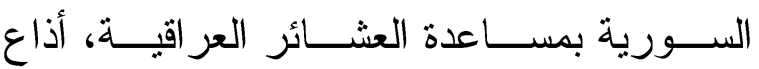

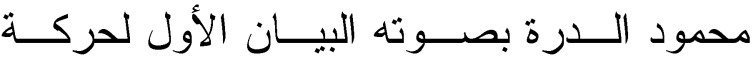
الموصل، ثم أذيع نشيد (اله أكبر) الــذي كــان

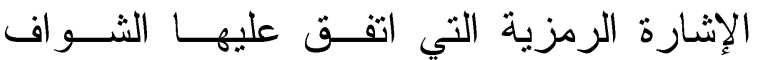

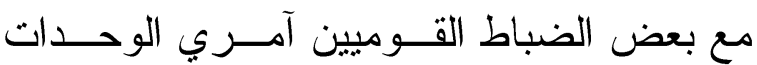

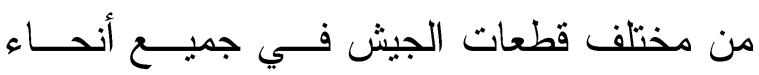

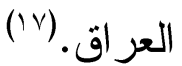

وبعد أن علم عبد الكريم قاسم بنبــأ إعــلان

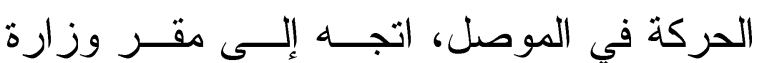

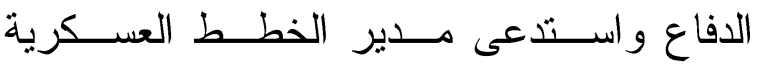

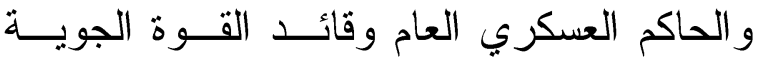

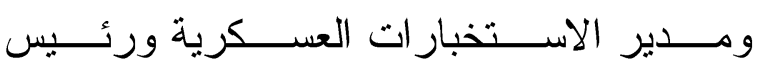

وتقابل الفريقان وحدث صــــام كبيــر بينهـــا،

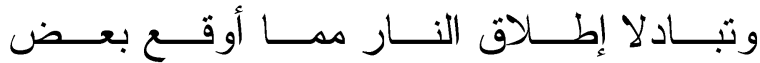

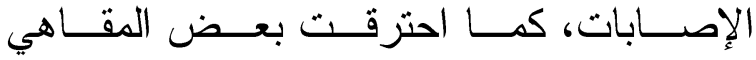
و المكتبات وتم تحطيم عـدد مـن الســبار ات، وفي عصر ذلــلك اليـوم بــــأ الثـــواف فـــي

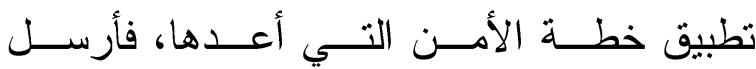

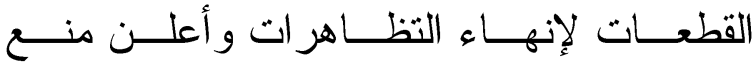
التجو ال، وقام بتسليح عناصــر القــوميين مــن أهالي المدينة بمســاعدة عشــائر شـــر التــي قامت بدور كبيــر فــــــــل الأســلحة عبــر

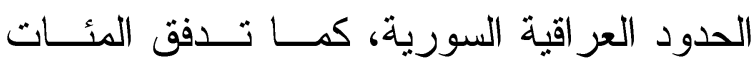

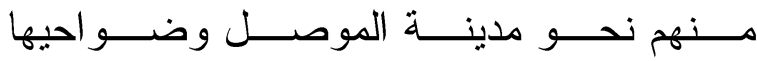
بانتظار أوامر القيادة، وألقى الثـــواف القــبض على كثير من زعمــاء الثــيوعيين و أنصــار

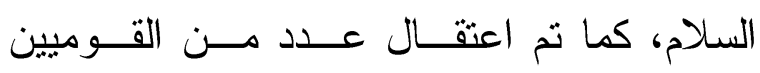
تمويهاً لحركته، حيث أفرج عنهم فــي المســـاء بينما ضيق الخناق حول الثيو عيين.(10)

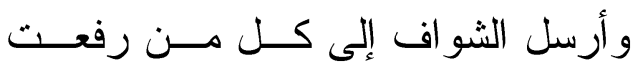

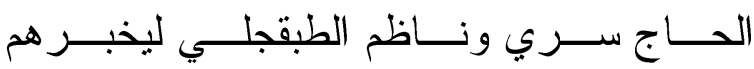

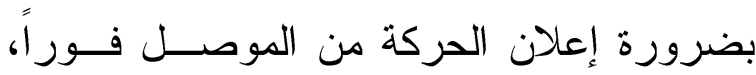

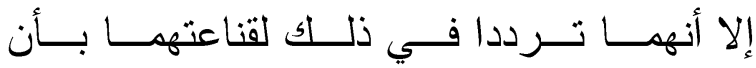

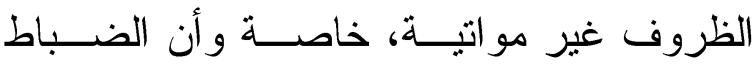
المو الين لعبد الكــريم قاســـم مــن الثـــيوعيين

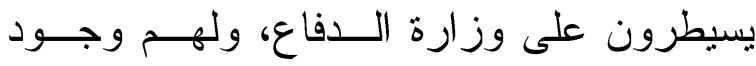
قوي في وحدات الفرقة الثانية فــي كـلـ مــن

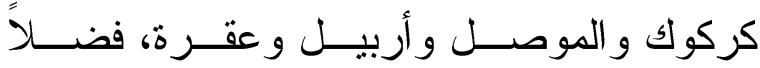
عن عدد كبير من البارتيين والكــرد الــــوالين

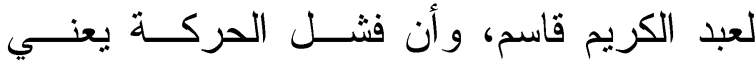

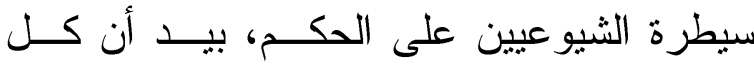




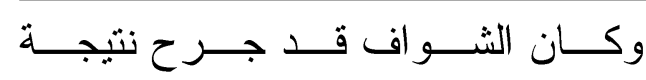

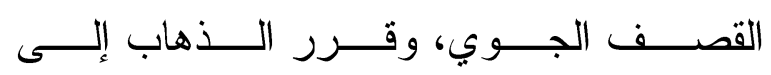

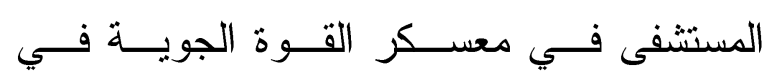

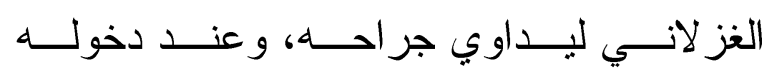

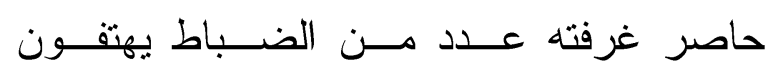

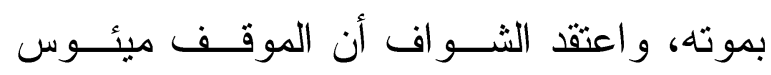

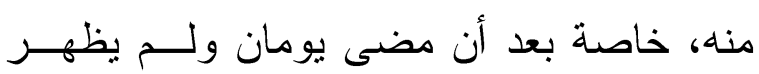

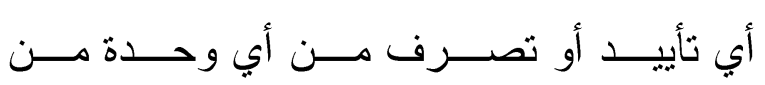
وحدات الجيش خارج الموصل لمســاندته فــي

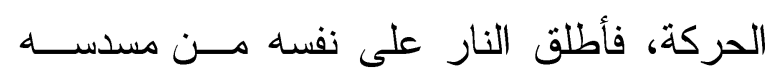
ولقي حتفه على الفور. (r)

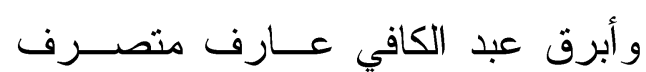

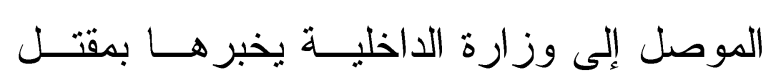

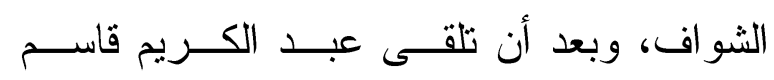

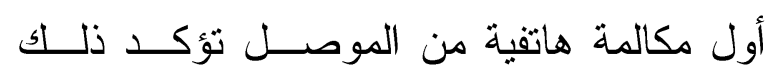

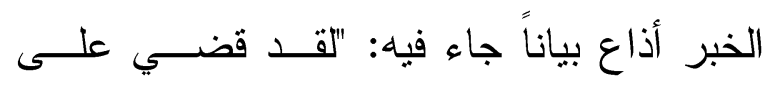

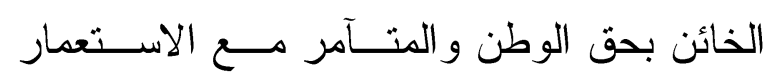

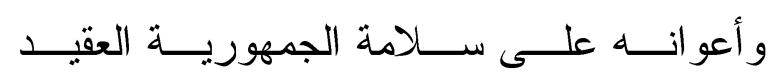

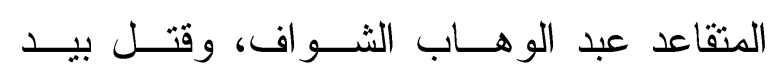
جنوده وضباطه وخاصــة المؤيــدين للــزعيم

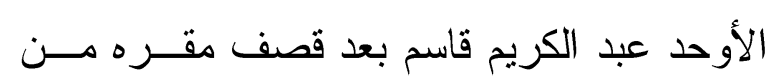

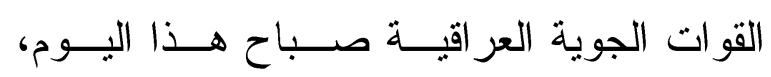

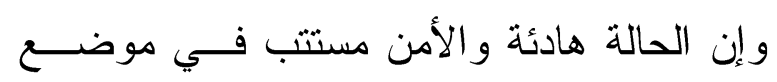

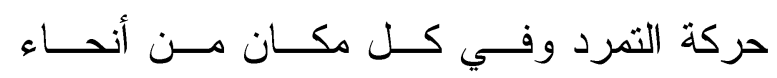

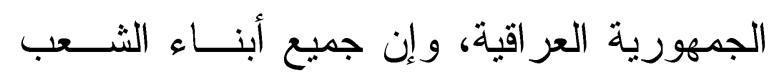

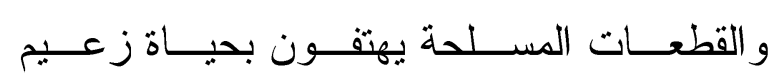

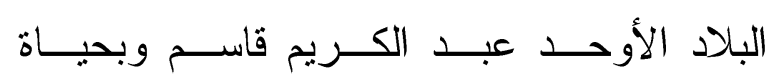
الجمهورية العر اقية الخالدة". (rr)
أركان الجيش، وطلب مــنهم الاتصـــال بكافــة

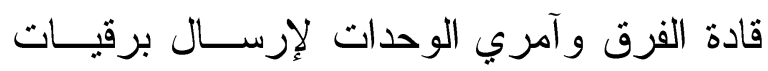

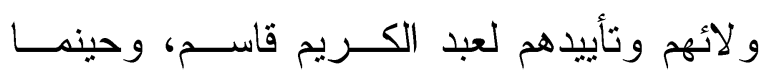

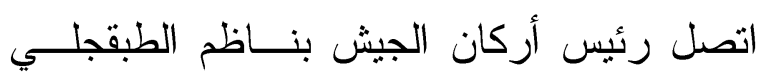

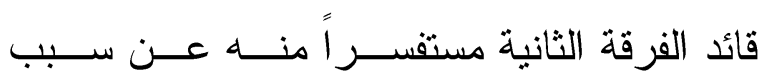

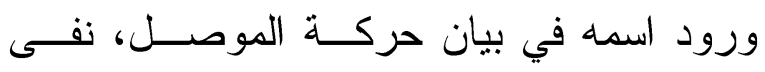
الطبقجلي أي صلة له بـذللك وبــادر بإرســال

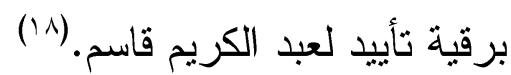

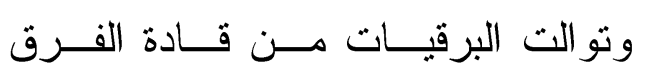

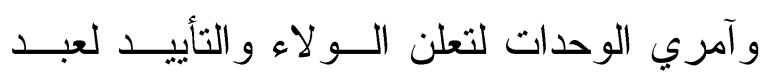

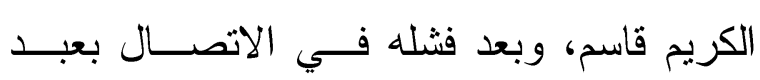
الوهاب الثواف أصـــدر مرســوماً جمهوريــاً

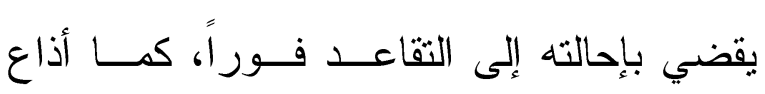

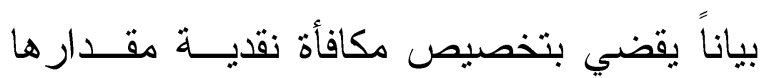
عشرة آلاف دينار لمن يقـبض عليـــه حبـــاً أو

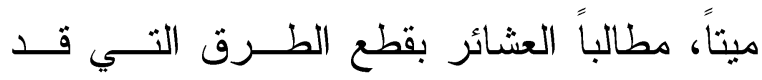
يستخدمها في العرب إلى خارج البلاد.(19) وفي صبح بـوم 9 آذار عـام 1909

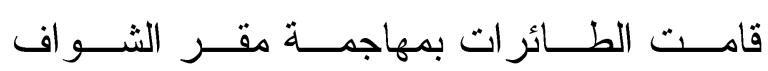

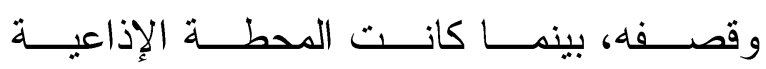

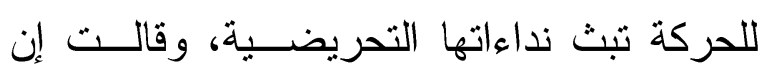

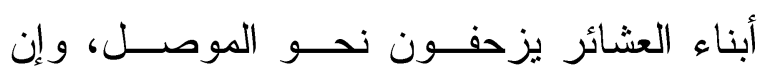

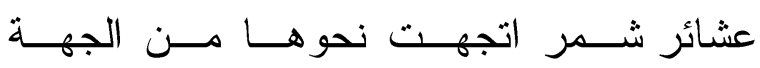

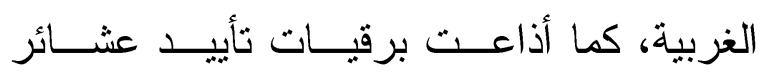

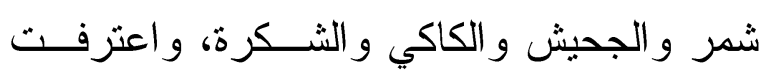

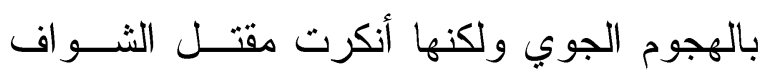

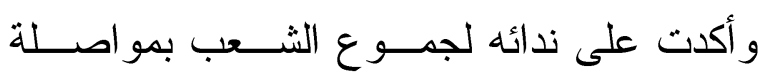
الكفاح. (r.) 
القوميون مــا لا يقـلـ عــن م ع شــــيداً فــي

صفوفهم وصــفوف حلفــائهج، وجعلـــوا عـدـد

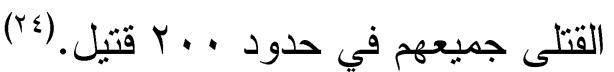

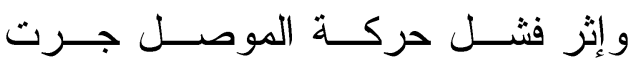

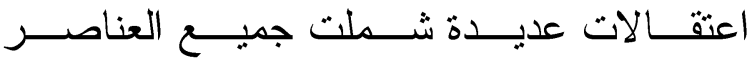
القومية سو اء داخل صفوف القــوات المســلحة

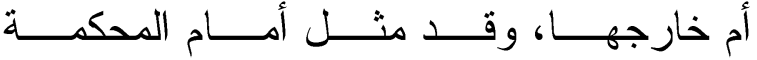
العسكرية العليا الخاصة بتهمة الاشـتر الك فـي حركة الموصل خمسة وســبعون متهمـــاً مــن ضــباط الجــيش ومــن المــدنيين، وصــدرت

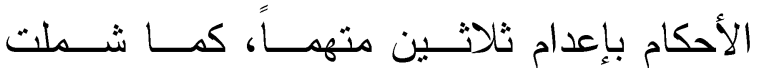

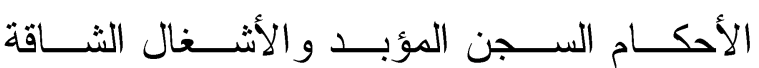
لسبعة و عشرين متهماً، بينما بــر أت المحكمـــة

$$
\text { ثمانية عشر متهماً. (ro) }
$$

\section{سادساً: أسباب فشل حركة الموصل}

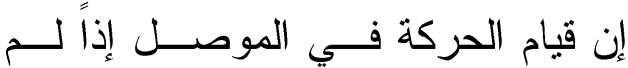

يكن سوى بدء الإشارة للقيــام بحركــة علــى نطاق واسع تتركز فـي بغــــاد وتعـــ جميــع

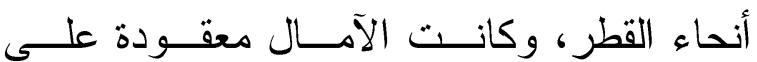

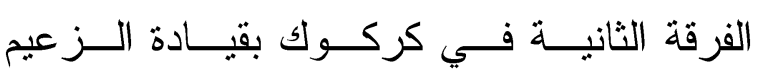
الركن ناظم الطبقجلــي ذات الأهميـــة البالغـــة من ناحيـــة قوتهــــا الضــــاربة مقارنــــة بفــرق الجيش الأخرى، الأمــر الـــي كــان ســيوفر

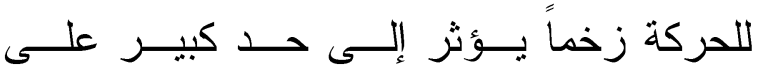
القطعات الأخــرى وعلــى زعزعــة الســلطة

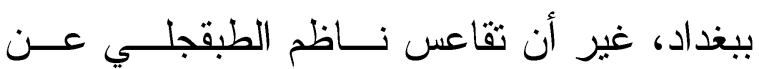
مساندة الحركة في الموصــل جعــل القطعــات

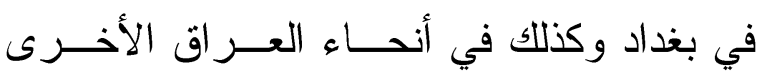
تتردد هي الأخرى عن التـــرد، الأمــر الــذي
و أصيب محمود عزيــز بالبــأس بعـــ

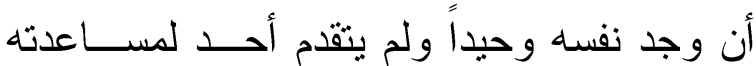
من خــارج الموصــل، فقــرر الانتقــام مــنـ الشيو عبين بقتل قادتهم، ووقعت معركــة بــين القــوميين المـــدافعين عــن الثكنـــة الحجريــــة

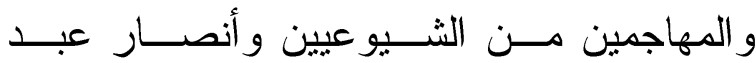

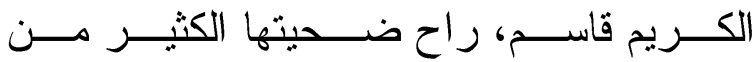

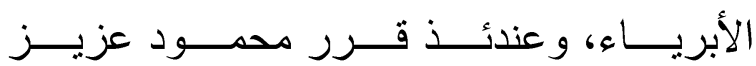

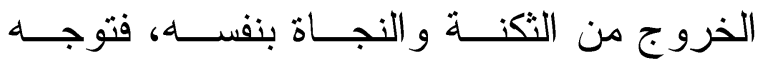
إلى باب سنجار ثــم إلــى الحــدود الســورية

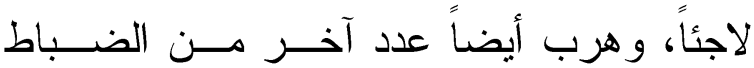

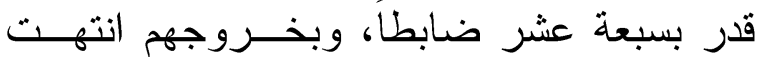

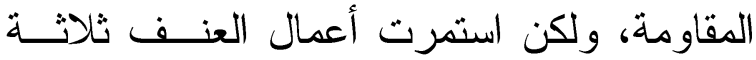

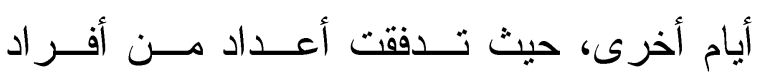
العشائر العربيـــة و الكرديـــة داخــــل المدينـــة، وشــكل الطــلاب و أفـــر اد المقاومــــة الشـــعبية و العشائر جماعــات تجــوب المدينــة وتفــتش البيوت و المحال للاقتصـــاص مــن القـومبين،

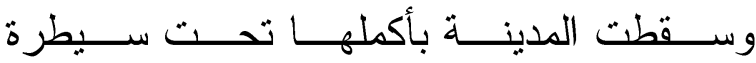

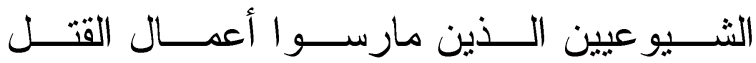

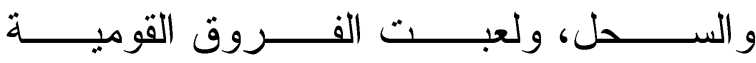

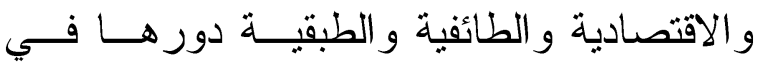
أعمال التحريض على القتل و الانتقام. (rr) ولقد اختلفــت المصــادر حــول عـدد ضحايا حركــة الموصــل، فحســب تقــدير ات الشيوعيين كان عـدد القتلـى • 11 والجرحسى

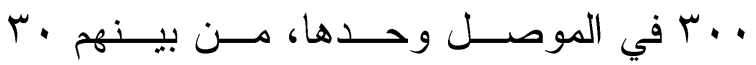

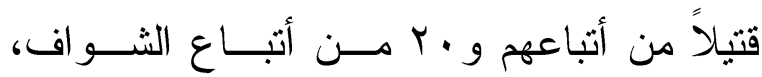

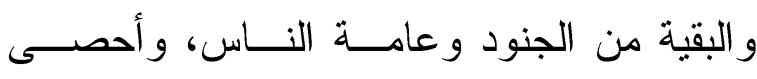


r- بـ ولم تعلم بها الأحزاب و القوى القوميــة

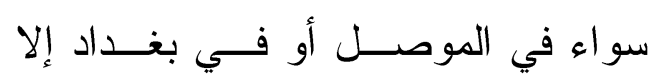

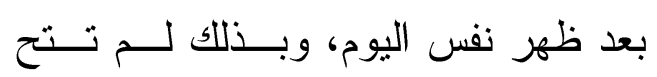
لها مساندتها في الوقت المناسب.

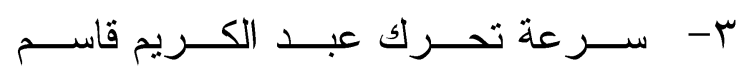

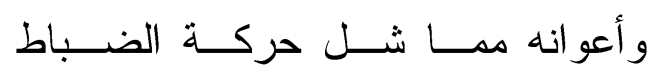

$$
\text { الأحر ار في بغداد. }
$$

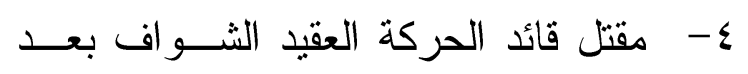

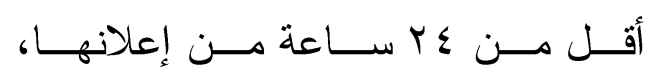

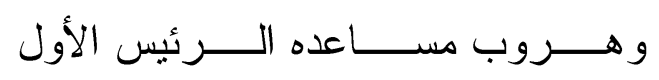

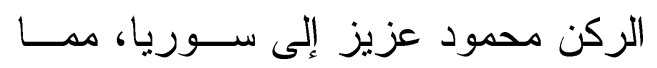

أدى إلى إضعاف الحركــة واستســلام

أغلبية القوات المشاركة فيها.

\section{سابعاً : نتائج حركة الموصل}

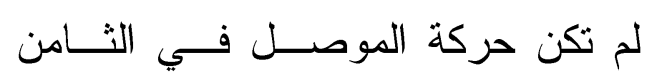

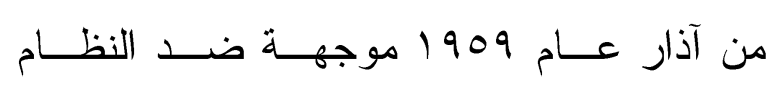

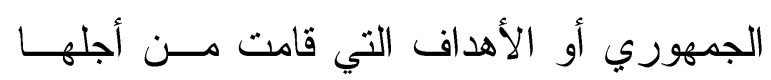

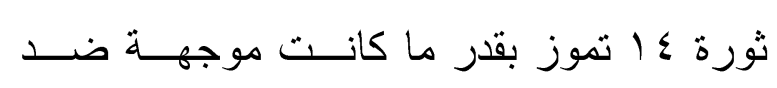

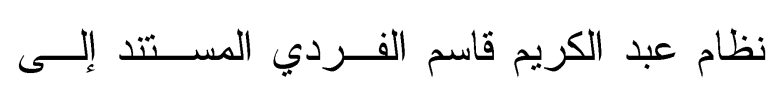

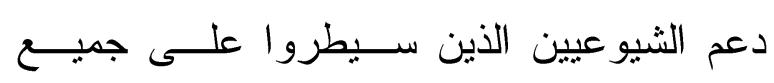

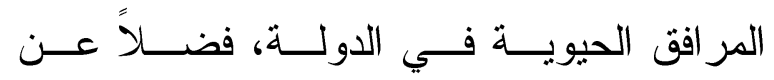

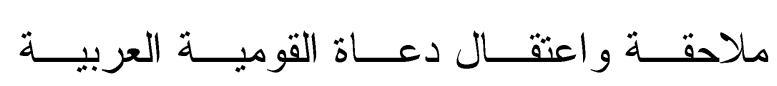

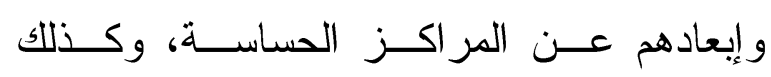

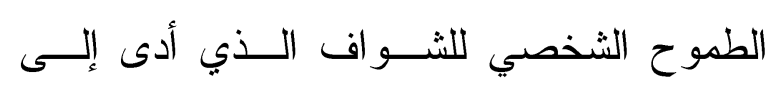

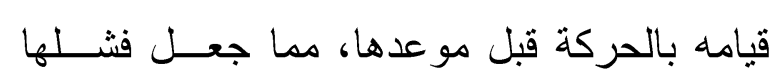

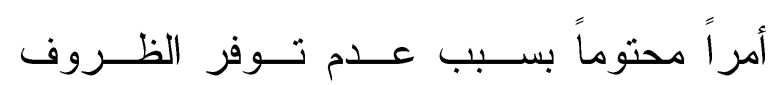

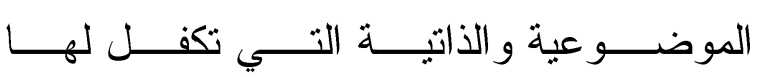

$$
\text { النجاح.(ra) (لموضوع }
$$

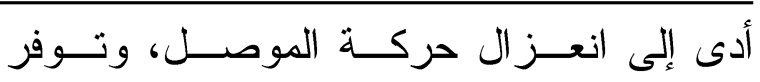

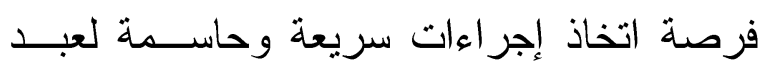

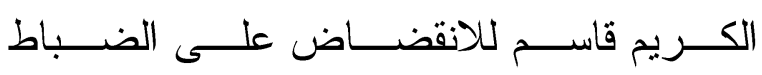
الموالين للحركة واعتقالهم، ثم ســـق الحركـــة

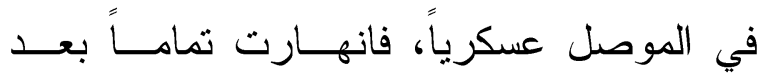

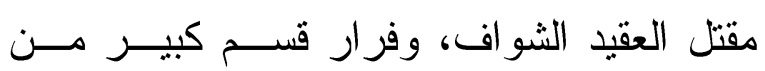
ضباطه إلى سوريا. (r)

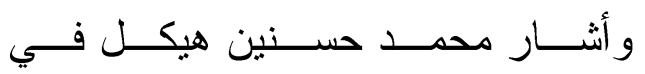

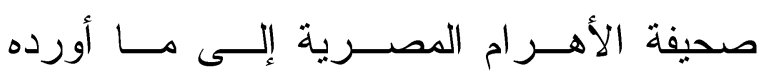

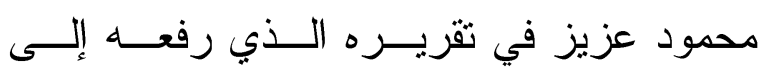

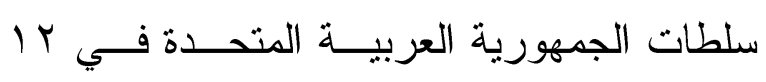

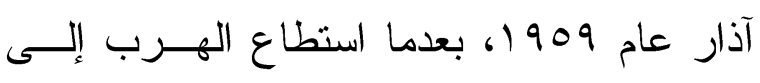
سوريا عبر الحدود مع العـراق، حيــث ثـــال: "كان في حركة الموصل من الفروســية أكثــر

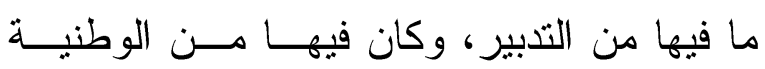

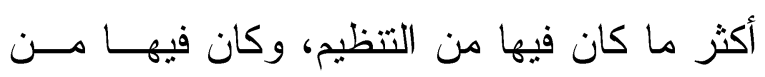

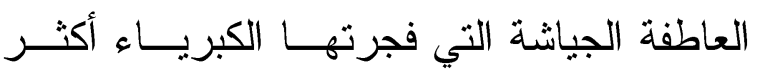

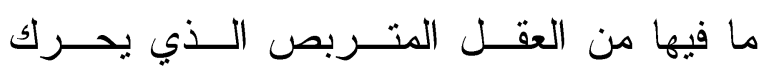

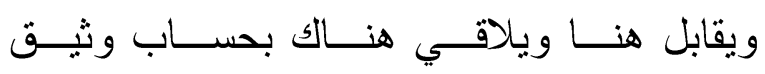

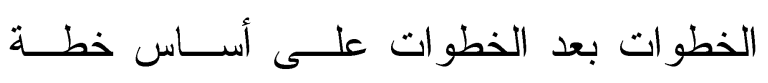
مدروسة إلى تفاصيل التفاصيل".(YV)

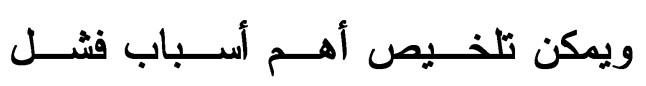

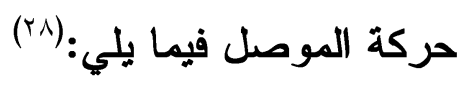

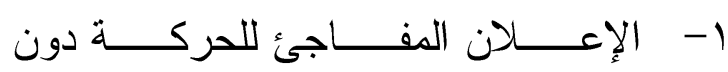

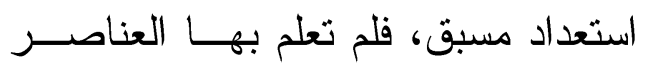

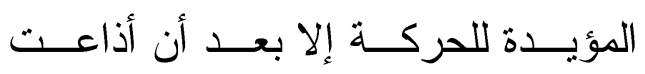

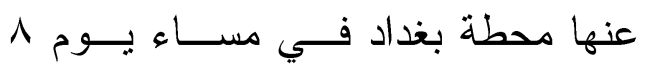
آذار عام 1909. 


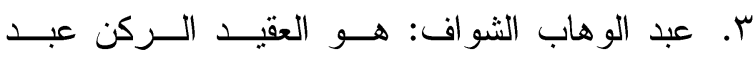

الوهاب عبد الملك الثواف، ولد فــي بغــداد عــام 1917 من أسرة هاجر أجدادها من جزيــرة ابــن

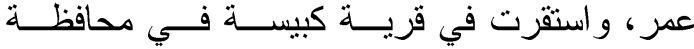

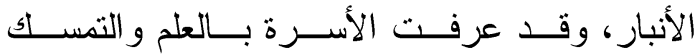

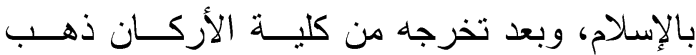

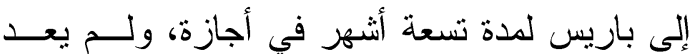
منها إلا عــام 90 19، ودخــل مدرســـة الأقــدمين في بريطانيا، وفــي الســنة التاليــة انتــى إلــى

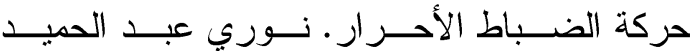
العاني و آخرون: مرجع سابق، ص آד-r آ.

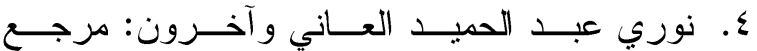

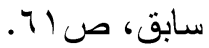

ه. ليث عبد الحسن الزبيدي: ص. •ب؛؛ نــوري عبــد الحميد العاني و آخرون: مرجع سابق، ص بآ.

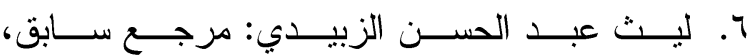

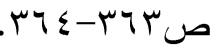

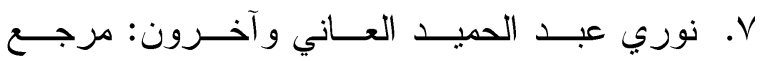

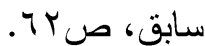

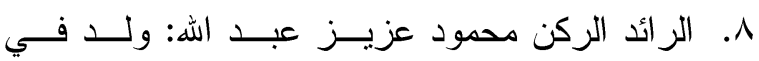

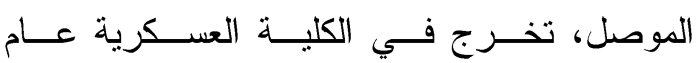

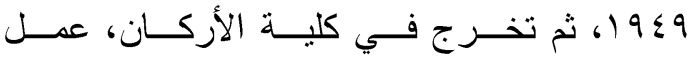

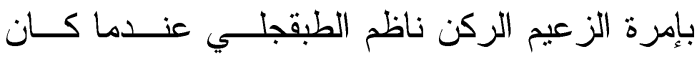

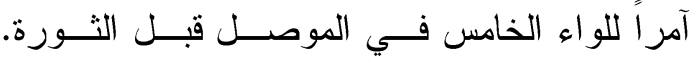

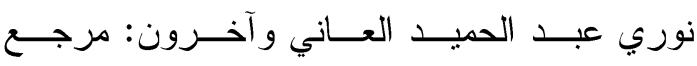

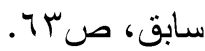

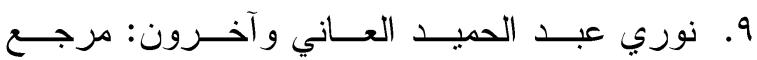

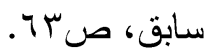

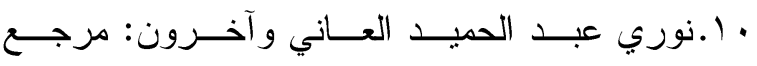

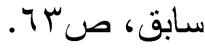
1 ا. العقيد رفعت الحاج ســري: ينتـــي إلــى عثــيرة

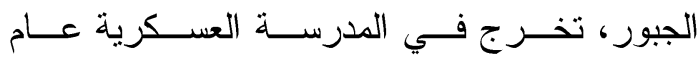

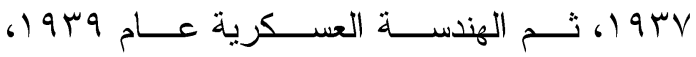
اشترك في ثورة إ9 1، وفـي حسرب فلســطين

\section{ورغم فشل حركة الموصـلـل إلا أنهـــا}

أدت إلى نتائج مهمة، وهي:(·)

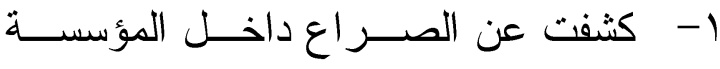

العسكرية بعد قبــام التــورة، وخاصــــة

بين أعضـــاء اللجنـــة العليــا للضـــباط

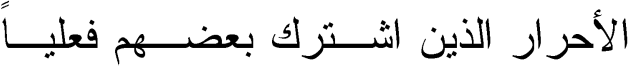

$$
\text { فيها يوم الثورة. (*) }
$$

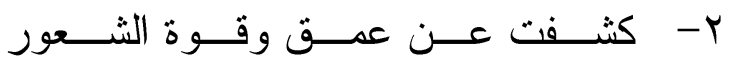

بالوحـــدة العربيــــة و القوميـــة العربيــــة

$$
\text { و المنادين بها. }
$$

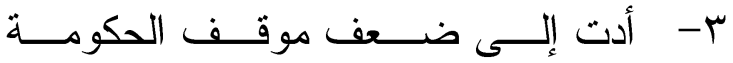
بسبب عدم و لاء الجيش لهــا و انقســامه

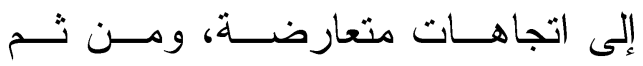
تدبيز خطــط للقضـــاء علــى النظــام القائم. ع - أججت الصر اع بين عبد الكـريم قاســم و الشيو عيين بسبب أعمال القـــع التـي حدثت فـي الموصــل، ثــم انصـــر افه

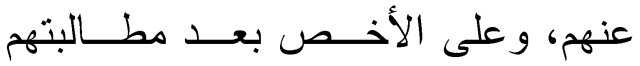
إياه بالاشتر الك في الحكم. - أدت إلى عزلة عبد الكريم قاســم بـين الأقطار العربيــة وازديــاد الحمـلات الإعلامية ضد نظام حكمه.

\section{هوامش البحث}

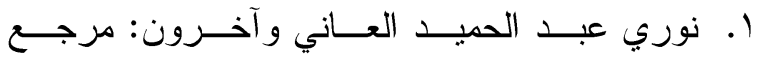
سابق، جr، ص101-09.09.

r. عبد الفتــاح علــي يحيــى: التطـــورات السياسـية

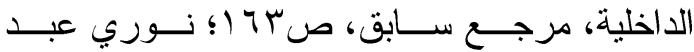

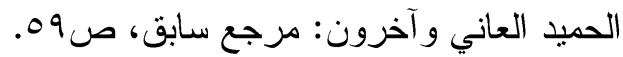


اY.نوري عبــد الحميــــ العــاني وآخـرون: مرجـع

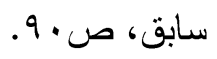

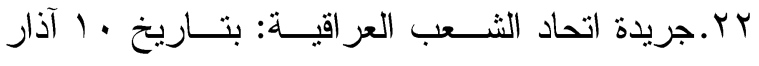
909 1؛ نوري عبــــ الحميــد العــاني وآخـرون:

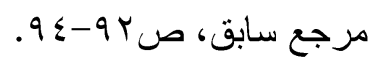

سب.خليل الزوبعي: العراق فــي الوثــائق البريطانيــة،

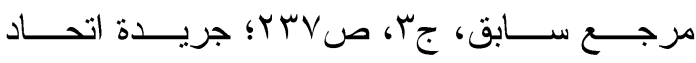

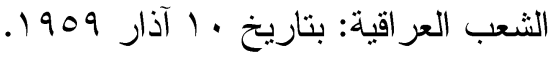
ـ ז.وقيل إن بعض الجنــود هــم مــن أطلقــوا النــار عليــــ. مجيـــد خــدوري: المحاكمـــات، مرجـــع

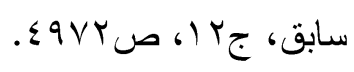

هY. خليــل إبــر اهيم حســين: موســوعة ؛ ا تمــوز،

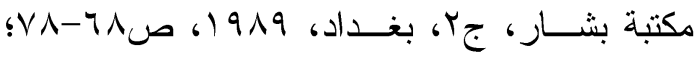
جريدة اتحاد الثـــب العر اقيــة: بتـــاريخ م ـا آذار

.1909

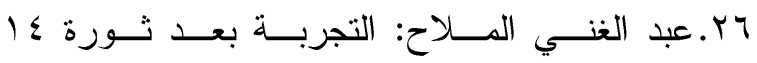

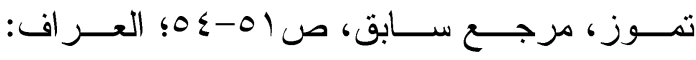

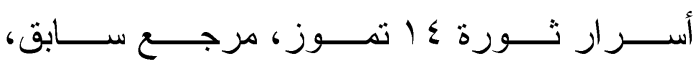

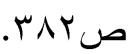

rV نوري عبـد الحميــد العــاني وآخـرون: مرجـع

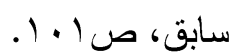

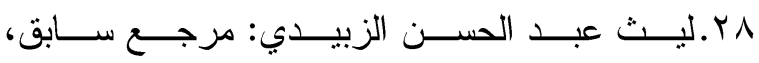

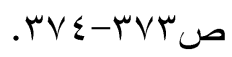
وr. محمود الدرة: ثورة الموصل بعــد ســبع ســنوات، مرجع سابق، ص Vگ؛؛ أحمد فــوزي: قصـــة عبــد

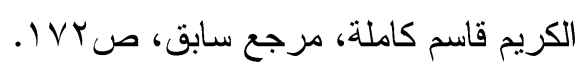

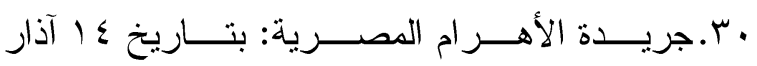
909 1؛ نوري عبــد الحميــــ العــاني وآخــرون:

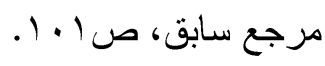

اس.طالب مشتاق: مذكرات سفير عراقي فـي نزكيــا،

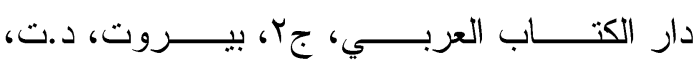

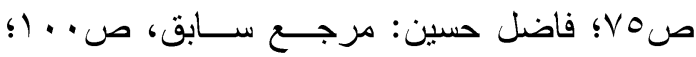

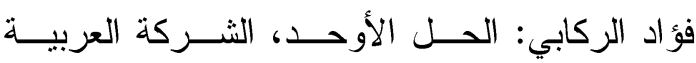
للطباعة و النشر، القاهرة، س79 (1، ص99 ب.
عام 9 19، وكان مــن أوائـلـ الضــباط الــذين

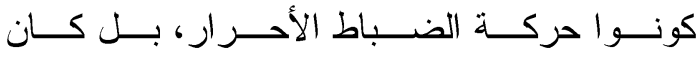
مؤسسها، وكــان بيتمتهـع بـــاحتر ام كبيــر بيــنـهم. نوري عبــد الحميــد العــاني وآخـرون: مرجــع

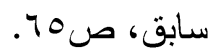
rا ـنوري عبــد الحميــد العــاني وآنـرون: مرجــع

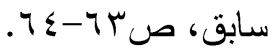
سا ـ عبد الفتــاح علــي يحيــى: التطــور ات السياســية

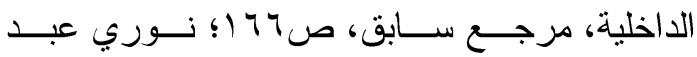

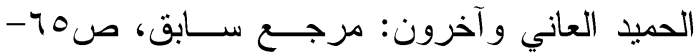

ـ ا ـمحمود الدرة: ثورة الموصل بعــد سـبع ســـوات، مجلة در اسـات عربية، الســنة الثانيــة، العــدد 7كات نيسان 1. جاسم مخلــص: مــذكرات الطبقجلــي وذكريـات

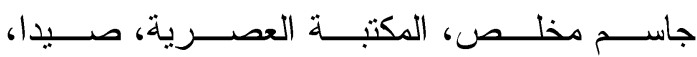
.

7 ا ـجريــدة اتحـــاد الثــعب: بتــاريخ r آذار 909 (؛؛ نوري عبــد الحميــد العــاني وآخـرون: مرجــع

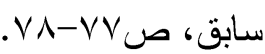

IV مجيــد خــدوري: العــراق الجمهـوري، مرجــع

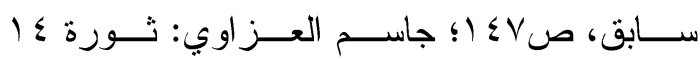

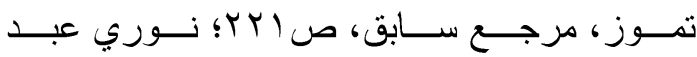

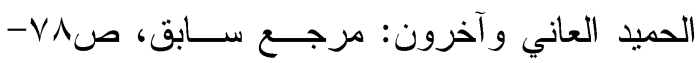

1 ا.مذكرات عبد اللطيف البغــدادي: مرجـع ســابق، ص اوج؟؛ العــارف: أســـرار ثـورة ع ا تمــوز، مرجع سابق، ص الی؟؛ عبد الفتاح علـي يحيـى:

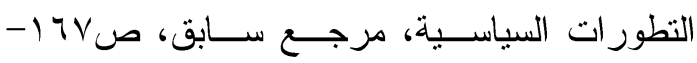
.179 9 ا.نوري عبــد الحميــد العــاني وآخـرون: مرجــع

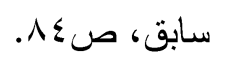

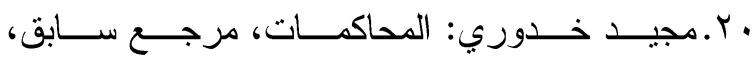

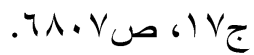


دار الطليعـة، بيــروت، 909 1، صـ ـ0؛ مديريــة

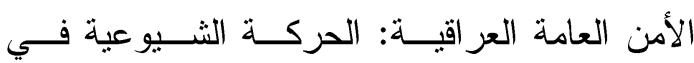

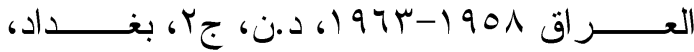
( ) a. وهم: العقيد الركن عبد الوهاب الثــــواف، العقيـــ

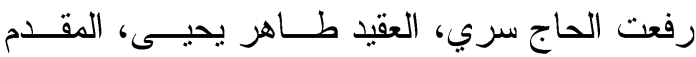
عبد الكريم فرحان، المقدم الطيار محمد سبع.
كس.ليــث عبــــ الحســن الزبيــدي: مرجـع ســابق،

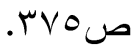
سا.حـزب البعـث العربــي الاشــتر اكي العراقـي: نضال البعث العربــي الاشــتر اكي عبـر بيانــات

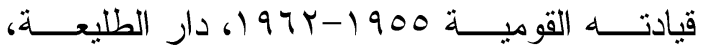

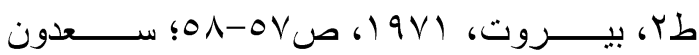

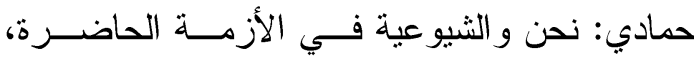

